\title{
Customer Expectation for Improvising the Comfortability of Royal Enfield two Wheelers
}

\author{
J. Kannan, D. Venkatrama Raju
}

\begin{abstract}
The LPG policies have lead to unremitting raise in rivalries which have eventually resulted in transformation in row by the universal values as fit as in considerable slice in price. Advertising of automobile investment company and bank division have too played a noteworthy position in boost vehicle require, particularly since the residents in the center revenue set. Currently numerous global brands like Honda, Suzuki, are rival with Indian brands such as Royal Enfield, Hero Honda, Bajaj, TVS, and Kinetic to imprison Indian Markets. These company track diverse advertising strategy have resulted in creation the end user the main input for winner in the business The genuine test is to create charmed clientele and additional highly faithful consumers. Customers are the sovereign and lacking fulfilling their wants nothing be able to live in the business spirited globe. The present study aims to investigate the consumer perception and satisfaction towards Royal Enfield Bike.
\end{abstract}

Keywords: Automobile Investment, Advertising Strategy, Consumer perception

\section{INTRODUCTION}

Automobile manufacturing is one of the major industries in the international market. Being the head in manufactured goods and practice technology in the modern sector, it has been standard as one of the drivers of monetary increase. In modern years, healthy heading for hard work have been made to offer an innovative appear and way to the automobile rule for realize the sector's complete possible for the financial system[1]-[4]. Every product offer novel intended to convene and go beyond the prospect of the clients. Perceptive and thoughtful the purchaser behavior is not at all easy for the sellers. It is mainly hard that to recognize what a user perceives regarding the product. Clients might declare single obsession except act an additional. They might not exist in feel among their deeper motivation. They are influenced by several factors and that modify their mind at the preceding instant.

It is being tough to satisfy the nearby day customers. The advertisement aware civilization twisted smarter and additional price aware and in rotate extra challenging and fewer merciful. They depart the competitor with parallel or at period still improved offer. So the face up to is not to construct for clients, some compact might act it.

Revised Manuscript Received on December 11, 2019

J. Kannan, Department of Science and Humanities, Bharath Institute of Higher Education and Research, Chennai , India. Email: sjkannan1986@gmail.com

D. Venkatrama Raju, Department of Science and Humanities, Bharath Institute of Higher Education and Research, Chennai, India. Email: prof.dvraju@gmail.com

\section{SCOPE OF THE STUDY}

The learn help in have an attentiveness of client awareness towards Royal Enfield. Since the manufactured goods have a good quality standing in the marketplace, this learning resolve assist to identify to how Royal Enfield missing their hold in motor bike business for the past years [5]-[8]. It also helps us to enhance our realistic information towards promotion of a business.

\section{A. Objective}

1. To analyses the consumer perception towards the Royal Enfield Bike.

2. To identified the customer awareness level of Royal Enfield bike and its different models.

3. To study the satisfaction of respondents on the performance, features, service ability and company image of Royal Enfield Bike.

4. To measure the Satisfaction level of people towards the Royal Enfield Bike.

5. To investigate the consumer insight towards services obtainable by Royal Enfield Bike and recital of the motor cycle.

6. To get feedback on what consumer expects from Royal Enfield Bikes.

\section{B. Hypothesis}

1. There is no significance relationship between Age and source of information[9]-[11].

2. There is no significance relationship between Educational qualification and Feature for respondents while purchase a bike.

3. There is no significance association among earnings level and acquire the bike.

\section{RESEARCH METHODOLOGY}

Methodology is defined as the specification of methods and procedures for acquiring the information needed. It is a plan or a framework within which the research has been undertaken.

\section{A. METHOD OF SAMPLING}

Sampling is a process of obtaining the information about an entire population by examining only a part of it. For the purpose of this study the researcher has used the Convenience sampling method

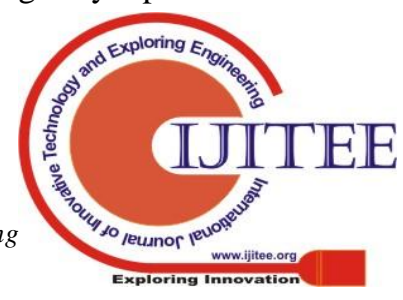




\section{Customer Expectation for Improvising the Comfortability of Royal Enfield two Wheelers}

and selected 100 customers randomly for the survey.

\section{B. CONSTRUCTION OF TOOLS}

The tool used for collecting data was questionnaire. A questionnaire is simply formalized schedule to obtain and record specified and relevant information, with tolerable accuracy and completeness[12]-[15]. The questionnaire is carefully constructed and properly setup. A Pilot study was conducted on a sample size of 20 respondents, right at the beginning of the survey. Based on the Pilot survey the researcher made a number of alterations in the questionnaire, to aid proper survey.

\section{SOURCE OF DATA}

Both the primary data and the secondary data are taken into account for the purpose of the study.

\section{PRIMARY DATA}

Primary data have been collected from among the target group (sample) by administering the questionnaire among the selected sample.

Statistical tools applied for the analysis of data are percentage analysis and Chi-square test.

\section{RESULTS AND DISCUSSIONS}

$45 \%$ of the respondents' age is below 25 years.

Majority $(100 \%)$ of the respondents are male.

$>$ It is clear that $70 \%$ of the respondents are post graduate

$>$ It is ascertained that $55 \%$ of the respondents were working in service sector.

$>$ It is analyzed that $55 \%$ of the respondents' level of Income are in between Rs.5000-15000.

$>$ It is found that $95 \%$ of the respondents have knowledge about Royal Enfield bike[16]-[19].

$>$ It is inferred that $45 \%$ of the respondents' sources of information about Royal Enfield from Friends and relatives.

$>40 \%$ of the respondents used model were classic $500 \mathrm{cc}$.

$>$ It is found that $65 \%$ of the respondents most required feature while purchase bike were style and power.

$>$ It is ascertained that order of the purchase preference given Rank One obtained Royal Enfield.

$>$ It is analyzed that $35 \%$ of the respondents owned model of Royal Enfield are others.

$>$ It is showed that $55 \%$ of the respondents' mode of purchase was loan.

$>$ It is found that $60 \%$ of the respondents buy the Royal Enfield while consider other motor cycle.

$>$ It is clear that $30 \%$ of the respondents' are compare with other bike and cc.
$>$ It is analyzed that $40 \%$ of the respondents purchase through showroom[25].

$>$ It is ascertained that $60 \%$ of the respondents are felt rarely about frequency of breakdown.

$>85 \%$ of the respondents prefer to purchase from showroom.

$>100 \%$ of the respondents are pleased with parts.

$>$ It is found out that $70 \%$ of the respondents felt that the spare parts are readily available.

$>$ It is inferred from the table that $40 \%$ of the respondents felt that there is high price low mileage.

$>$ It is clear from the table that $70 \%$ of the respondents' level of satisfaction with respect to power and pickup are good.

$>$ It is indicated that $65 \%$ of the respondents' level of satisfaction with respect to comfort and safety are good.

$>$ It is found out that $65 \%$ of the respondents' feel the service are good[20]-[22].

$>35 \%$ of the customers' friends felt that the bikes are high cost and low mileage.

$>$ It is found out that $40 \%$ of the respondents not purchased due to high price.

$>$ It is inferred that $60 \%$ of the respondents done service at showroom.

$>$ It is ascertained that $90 \%$ of the respondents felt that they satisfied with their replies.

$>$ It is indicated that $55 \%$ of the respondents suggested less than 2 times to friends and relatives to purchase Royal Enfield Bike.

\section{SUGGESTIONS}

$>$ Company tries to reduce the price.

Company provides enough information regarding effective maintenance[23]-[24].

Make use of additional promotional technique to develop the sale in upcoming. Perform additional path show/open exhibit that creates public awareness.

$>$ It also produces bikes for women.

\section{CONCLUSION}

Introduction of different models is one of the biggest threats to other two wheeler manufacturer. It holds an imperative put in the mind of 
buyer by given that well-organized service and enhanced goods. Manufactured goods competence and discover are the technique they exist up nowadays. Consumer perception towards Royal Enfield motor cycles is extremely excellent.

It have shaped a incredibly high-quality make picture used for itself by on condition that small preservation, smooth look model the length of through well-organized following sale services and it have involved each group of clientele.

\section{REFERENCES}

1) Vasanthi, S. \& Rabiyathul Basariya, S. 2019, "Influence of value analysis and cross training in industry", International Journal of Engineering and Advanced Technology, vol. 8, no. 6, pp. 1810-1811.

2) Velvizhi, R., Sri Gowtham, S. \& Jeya Priya, D. 2019, "Examination of early feedbacks for effective product retailing on E-commerce websites", International Journal of Engineering and Advanced Technology, vol. 8, no. 6 Special Issue 2, pp. 703-706.

3) Anuradha, C., Pothumani, S. \& Kavitha, R. 2019, "A novel method towards E-commerce", International Journal of Engineering and Advanced Technology, vol. 8, no. 6 Special Issue 2, pp. 535-538.

4) Thomas, J. \& Rabiyathul Basariya, S. 2019, "A study on the issues of financial ratio analysis", Indian Journal of Public Health Research and Development, vol. 10, no. 3, pp. 1079-1081.

5) Ramachandran, S. \& Rabiyathul Basariya, S. 2019, "Online marketing study on customer satisfaction and relationship", Indian Journal of Public Health Research and Development, vol. 10, no. 3, pp. 1072-1078.

6) Priya, R., Vinothini, G. \& Cor Jesu, C.D. 2019, "The mentor-protégé relationship for professional growth", Journal of Advanced Research in Dynamical and Control Systems, vol. 11, no. 9 Special Issue, pp. 1110-1119.

7) Jannifer Rani, N., Bina Pani, S. \& Nimisha, N.S. 2019, "A study on money back polices available in LIC", Journal of Advanced Research in Dynamical and Control Systems, vol. 11, no. 9 Special Issue, pp. 833-839.

8) Saillaja, V., Jhansi Rani, K. \& Catherine, R. 2019, "Global marketing management planning and organization", Journal of Advanced Research in Dynamical and Control Systems, vol. 11, no. 9 Special Issue, pp. 489-493.

9) Saillaja, V., Jhansi Rani, K. \& Catherine, R. 2019, "The new phase of marketing information system", Journal of Advanced Research in Dynamical and Control Systems, vol. 11, no. 9 Special Issue, pp. 482-488

10) Thoufiqulla \& Raju, D.V. 2019, "Perception of indian investor towards investment in mutual funds with special reference to mip funds", Journal of Advanced Research in Dynamical and Control Systems, vol. 11, no. 5, pp. 177-183.

11) Jasmine, K.R.M. \& Basariya, S.R. 2018, "A study on the customers benefits on mutual funds", International Journal of Civil Engineering and Technology, vol. 9 , no. 4 , pp. $45-48$

12) Vasanthi, S. \& Basariya, S.R. 2019, "Pros and cons of on the job training versus off the job training", International Journal of Scientific and Technology Research, vol. 8, no. 10, pp. 671-674.

13) Pavithra, J. \& Ganesan, M. 2016, "A study on awareness and impact of micro-financial schemes", International Journal of Applied Business and Economic Research, vol. 14, no. 8, pp. 5449-5460.

14) Pavithra, J., Dilli Babu, P. \& Ambuli, T.V. 2014, "A study on budgetary control at Maruti Service Masters, Chennai", International Journal of Applied Business and Economic Research, vol. 12, no. 2, pp. 151-161.

15) Gunaraja, T.M. \& Venkatrama Raju, D. 2018, "Determining factors of organisational climate with reference to leadership styles", International Journal of Mechanical Engineering and Technology, vol. 9, no. 9, pp $1327-1332$

16) Gunaraja, T.M. \& Venkatrama Raju, D. 2018, "The role of job satisfaction and training of employees in determining organisational climate of a selected industry", International Journal of Civil Engineering and Technology, vol. 9, no. 8, pp. 1266-1269.

17) Aarathy, T.S. \& Raju, D.V. 2018, "Performance appraisal and its effects on employees with respect to it sector in Chennai city", International Journal of Civil Engineering and Technology, vol. 9, no. 6, pp. 1535-1538.

18) Aarathy, T.S. \& Raju, D.V. 2018, "Employee perception towards performance appraisal system in IT sector", International Journal of Mechanical Engineering and Technology, vol. 9, no. 5, pp. 131-135.

19) Porselvi, W., Jublee, D. \& Sivanesan, G. 2018, "A study on factors influencing adoption of technology and innovation in banking industry, tamilnadu, India", International Journal of Mechanical Engineering and Technology, vol. 9, no. 5, pp. 789-800.

20) Akessa, G.M. and Dhufera, A.G., 2015. Factors That Influences Students Academic Performance: A Case of Rift Valley University, Jimma, Ethiopia. Journal of Education and Practice, 6(22), pp.55-63.

21) Miller, G. and Shih, C.C., 1999. A faculty assessment of the academic rigor of on-and off-campus courses in agriculture. Journal of Agricultural Education, 40, pp.57-65

22) Tsinidou, M., Gerogiannis, V. and Fitsilis, P., 2010. Evaluation of the factors that determine quality in higher education: an empirical study. Quality Assurance in education, 18(3), pp.227-244.

23) Farooq, M.S., Chaudhry, A.H., Shafiq, M. and Berhanu, G., 2011 Factors affecting students' quality of academic performance: a case of secondary school level. Journal of quality and technology management, 7(2), pp.1-14

24) Fitsilis, P., Gerogiannis, V. and Anthopoulos, L., 2014. Ontologies for software project management: a review. Journal of Software Engineering and Applications, 7(13), p.1096.

25) Adams, J.D. and Jaffe, A.B., 1996. Bounding the effects of R\&D: an investigation using matched establishment-firm data(No. w5544) National bureau of economic research.

\section{AUTHORS PROFILE}

J. Kannan Associate Professor, Department of Science and Humanities, Bharath Institute of Higher Education and Research, Chennai , India.

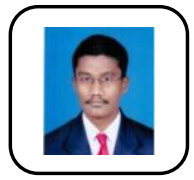

D. Venkatrama Raju Professor, Department of Science and Humanities, Bharath Institute of Higher Education and Research, Chennai, India.

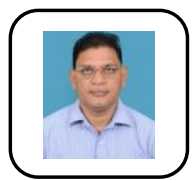

